\title{
KEPASTIAN HUKUM PEMENUHAN HAK KREDITOR DALAM EKSEKUSI OBJEK JAMINAN HAK TANGGUNGAN MELALUI PARATE EKSEKUSI
}

\author{
Deasy Soeikromo \\ Fakultas Hukum Universitas Sam Ratulangi Manado \\ E-mail: soeikromod@yahoo.co.id
}

\begin{abstract}
By the existing Law Number 4 of 1996 concerning Land Mortgage has given a chance to creditor to sell all assets which is collateralized by debtor without court process. This thing happens to avoid "litigation adjudication" which is taken long time for finishing the problem. Because of that, when debtor fails to fulfill the obligation (wanprestasi), so the creditor party does not need to sue the debtor, but through "execution parate" which is known before as State Auction Service Office to be auctioned in public. Parate executie ruled in Law Number 4 of 1996 concerning Land Mortgage aimed to creditor gains easily the credit from debtor who fails to fulfill the obligation. At the time, creditor could sell the object of land mortgage without court decision. However this way does not used for some creditors because the confusion the regulation it self about parate executie in Law Number 4 of 1996 concerning Land Mortgage.
\end{abstract}

\section{Kata Kunci: Kepastian Hukum, Hak Kreditor, Ekseskusi, Hak Tanggungan}

\section{A. Latar Belakang}

Perencanaan pembangunan hukum nasional harus searah dengan pembangunan di sektor lainnya, khususnya penyesuaian dan pembaharuan hukum yang merupakan sarana dan prasarana bagi pembangunan ekonomi. Pembangunan ekonomi sebagai bagian dari pembangunan nasional, merupakan salah satu upaya untuk mewujudkan kesejahteraan rakyat yang adil dan makmur berdasarkan Pancasila dan Undang Undang Dasar 1945 (Hartono 1991: 35). Oleh sebab itu, perkembangan dalam bidang ekonomi yang sangat pesat tanpa diimbangi pembaharuan dan pembentukan hukum yang sesuai akan menimbulkan ketimpangan, bahkan dapat membahayakan perkembangan bidang ekonomi itu sendiri (Hasan 1996: 8), karena dalam dunia bisnis diperlukan adanya sarana dan pranata hukum yang kuat dan dapat memberikan kepastian, khususnya untuk menyelesaikan masalah-masalah pelaksanaan pembangunan ekonomi nasional. 
Selain sarana dan pranata hukum yang kuat, pelaksanaan kegiatan pembangunan juga membutuhkan penyediaan modal, karena modal merupakan salah satu faktor penentu dapat terlaksananya pembangunan ekonomi atau tidak. Salah satu sumber dana untuk penyediaan modal bagi masyarakat, baik untuk perorangan maupun bagi dunia usaha adalah dari pihak bank. Pendanaan dari pihak bank dapat dilakukan, baik untuk kegiatan konsumtif, maupun kegiatan produktif pada masyarakat yang dapat diberikan dalam bentuk kredit perbankan.

Sehubungan dengan kegiatan pembangunan ekonomi dan dalam kaitannya dengan kredit perbankan, maka tugas bidang hukum adalah untuk menciptakan keseimbangan baru antara kepentingan konsumen, para pengusaha, masyarakat dan pemerintah (Hartono 1991: 55). Mengingat pentingnya kedudukan dana perkreditan dalam proses pembangunan, maka merupakan suatu keharusan jika antara pihak pemberi dan penerima kredit dan pihak lain untuk memperoleh kepastian hukum melalui suatu lembaga hak jaminan yang kuat. Tujuannya adalah untuk memberikan rasa aman dan kepastian bagi semua pihak yang berkepentingan sebagai upaya untuk mengantisipasi timbulnya risiko kerugian, baik bagi kreditor maupun debitor yang memanfaatkan jasa perbankan.

Berdasarkan Pasal 1 angka 11 Undang-undang Nomor 7 Tahun 1992 tentang Perbankan, ditentukan bahwa kredit adalah penyediaan uang atau tagihan yang dapat dipersamakan dengan itu, berdasarkan persetujuan atau kesepakatan pinjam-meminjam antara bank dengan pihak lain yang mewajibkan pihak peminjam untuk melunasi hutangnya setelah jangka waktu tertentu dengan jumlah bunga, imbalan atau pembagian hasil keuntungan.

Sebagaimana telah diubah dengan Undang-undang Nomor 10 Tahun 1998 tentang Perubahan Undang-undang Nomor 7 Tahun 1992 tentang Perbankan (selanjutnya disebut UU No. 10 Tahun 1998), menentukan bahwa kredit adalah penyediaan uang atau tagihan yang dapat dipersamakan dengan itu, berdasarkan persetujuan atau kesepakatan pinjam meminjam antara bank dengan pihak lain yang mewajibkan pihak peminjam melunasi utangnya setelah jangka waktu tertentu dengan pemberian bunga (Usman 1998: 7). 
Kredit dapat berupa uang atau tagihan yang nilainya diukur dengan uang, misalnya bank membiayai kredit untuk menambah modal usaha, investasi baru, pembelian rumah, atau pembelian mobil. Perkreditan merupakan proses pembentukan asset bank. Kredit merupakan risk asset bagi bank, karena asset bank itu dikuasai pihak luar bank, yaitu para debitor. Setiap bank menginginkan dan berusaha keras agar kualitas risk asset ini sehat dalam arti produktif dan collectable, tetapi kredit yang diberikan kepada para debitor selalu memiliki resiko berupa kredit tidak dapat kembali tepat pada waktunya yang dinamakan kredit bermasalah atau non perfoming loan (NPL).

Kredit bermasalah dan kredit macet pada suatu bank pada prinsipnya dapat dihindari atau diminimalisir dengan cara menerapkan prinsip kehati-hatian (prudential banking principle) dalam pengelolaan usaha bank (Fokus Media 2001: 148). Penerapan prinsip kehati-hatian ini, dilakukan dengan menerapkan prinsip manajemen bank yang sehat dengan mengikuti ketentuan UU No. 10 Tahun 1998, maupun aturan yang dikeluarkan oleh Bank Indonesia selaku regulator perbankan di Indonesia, misalnya yang terkait dengan kecukupan modal $(C A R)$, batas maksimum pemberian kredit (BMPK), pengawasan nasabah (know your customer principle) dan manajemen risiko (risk manajemen). Hal tersebut dapat menjadikan bank sehat dan terhindar dari permasalahan-permasalahan antara lain terjadinya resiko kredit macet dalam jumlah besar, yang akan berpengaruh terhadap tingkat kesehatan suatu bank.

Pemberian kredit oleh pihak bank juga memperhitungkan risiko, termasuk risiko kredit tersebut tidak dapat dibayar oleh debitor yang telah menerima kredit karena macet. Meski pihak bank telah menerapkan prinsip kehati-hatian dalam pengelolaan kreditnya, tetapi tidak jarang kredit yang telah disalurkan kepada debitor mengalami masalah, bahkan kredit tersebut mengalami kemacetan. Macetnya kredit tersebut dipengaruhi banyak faktor, antara lain karena kesalahan manajemen debitor, ketidakpastian iklim usaha, atau penyebab lain misalnya spekulasi dari pengelola usaha yang menyebabkan debitor tidak mampu membayar kewajiban-kewajibannya pada kreditor. 
Macetnya kredit debitor tersebut dapat menyebabkan debitor dituntut pailit oleh kreditor, karena ketidakmampuan debitor untuk melunasi kewajibannya kepada kreditor. Kepailitan merupakan eksekusi massal yang ditetapkan dengan keputusan hakim, yang berlaku serta merta, dengan melakukan penyitaan umum atas semua harta orang yang dinyatakan pailit, baik yang ada pada waktu pernyataan pailit, maupun yang diperoleh selama kepailitan berlangsung, untuk kepentingan semua kreditor, yang dilakukan dengan pengawasan pihak yang berwajib.

Agunan debitor merupakan salah satu jaminan yang bernilai dan memiliki fungsi untuk penyelamatan akhir bila terjadi kemacetan kredit. Untuk menutupi kerugian yang diderita oleh pihak bank, maka pelaksanaan atau realisasi atau eksekusi terhadap jaminan debitor dapat dilakukan sesuai ketentuan hukum yang berlaku.

Hukum telah mengatur mengenai eksekusi terhadap jaminan kredit debitor yang telah diserahkan kepada pihak bank sebagai kreditor, namun demikian dalam pelaksanaannya ternyata tidak mudah. Untuk itu, diperlukan terobosan hukum untuk mengatasi debitor bank yang nakal. Hal ini karena banyak pembeli lelang yang sering dihalang-halangi debitor saat akan menguasai aset yang dibelinya. Padahal, pihak bank sebagai kreditor telah memenuhi prosedur panjang lelang, termasuk mengeluarkan dana yang tak sedikit.

Halangan dari pihak debitor sering muncul ketika pemilik barang (debitor) yang dilelang enggan melepaskan assetnya. Padahal, sesuai ketentuan, barang tersebut harus berpindah tangan, seperti yang telah tercantum dalam Sertifikat Hak Tanggungan (SHT) yang dikeluarkan oleh pihak Badan Pertanahan. Dengan sertifikat itu, pembeli lelang (kreditor) sebenarnya diperbolehkan menguasai objek lelang tersebut secara langsung. Sebab, Sertifikat Hak Tanggungan (SHT) memiliki kekuatan eksekutorial. Dengan kata lain, upaya paksa untuk mengambil alih aset tersebut dilindungi oleh undang-undang.

Upaya paksa pengambilalihan aset dilakukan karena debitor tidak mau melepaskan jaminan, sehingga pemenang lelang harus melakukan upaya pengosongan paksa dan upaya itu hanya dapat dilakukan oleh pengadilan. Proses 
di pengadilan akan membutuhkan waktu yang lama dan biaya yang tidak sedikit, artinya pemenang lelang terpaksa mengeluarkan biaya dua kali. Hal ini tentunya tidak memberikan kepastian hukum terhadap pihak kreditor, dengan kata lain kasus tersebut menyebabkan SHT hanya menjadi macan kertas. Hal ini disebabkan karena SHT mempunyai hak eksekutorial, akan tetapi masih diperlukan lembaga lain untuk melakukannya.

Munculnya regulasi baru tahun 1996 melalui Undang-undang No. 4 Tahun 1996 tentang Hak Tanggungan, memungkinkan kreditor untuk menjual aset yang diagunkan debitor tanpa campur tangan peradilan sudah tepat. Hal tersebut untuk menghindari jalur "ajudikasi litigasi" (proses hukum di pengadilan) yang prosesnya panjang dan memakan waktu, dan oleh sebab itu, ketika debitor wanprestasi, maka pihak kreditor tidak perlu menggugat lagi ke pengadilan untuk dapat menguasai haknya, tapi dapat diajukan ke lembaga parate eksekusi yang dahulu bernama Kantor Lelang Negara untuk dilelang di depan umum.

Parate executie yang diatur dalam Undang-undang Hak Tanggungan, bertujuan untuk memberikan kemudahan kepada kreditor dalam pemenuhan piutangnya manakala debitor wanprestasi, di mana kreditor dapat menjual objek Hak Tanggungan atas kekuasaan sendiri tanpa harus melalui lembaga peradilan. Kemudahan yang dimiliki kreditor tersebut kenyataannya tidak dapat dimanfaatkan karena terjadi kerancuan pengaturan mengenai parate executie dalam Undang-undang Hak Tanggungan (UU No. 4 Tahun 1996). Aturan dalam Undang-undang Hak Tanggungan menyebutkan bahwa hak untuk menjual objek Hak Tanggungan atas kekuasaan sendiri (eigenmachtige verkoop) lahir karena undang-undang, tetapi di sisi lain pada KUH Perdata ditentukan lahir dari perjanjian, sehingga hal ini menimbulkan makna ganda/kabur. Demikian juga terhadap prosedur pelaksanaan parate executie terdapat kontroversi, karena di satu sisi diatur bahwa penjualannya melalui pelelangan umum, sedangkan pada sisi yang lain harus melalui fiat pengadilan. Akibatnya prosedur pelaksanaan parate executie menimbulkan konflik norma. Di samping itu adanya kesesatan dalam penalaran terhadap Penjelasan Umum Angka 9 UUHT yang mengatur lembaga parate executie. 
Realita masih banyaknya kendala pada pengelolaan perbankan nasional, dimana pihak bank seringkali menghadapi kredit macet yang memiliki unsur kesengajaan dari pihak debitor (debitor wanpestasi), selain juga masih banyaknya hambatan dalam pelaksanaan eksekusi benda jaminan yang menjadi objek Hak Tanggungan. Sebenarnya telah ada prosedur eksekusi Hak Tanggungan yang dapat dilaksanakan secara lebih mudah, biaya lebih murah dan lebih cepat dibandingkan eksekusi berdasarkan Sertifikat Hak Tanggungan, yaitu melalui parate executie. Hal ini sudah merupakan hak kreditor pemegang Hak Tanggungan pertama untuk menjual obyek Hak Tanggungan atas kekuasaan sendiri melalui pelelangan umum.

Permasalahan yang muncul adalah kadangkala parate executie tidak dapat dilaksanakan, sehingga hal ini merugikan bagi pihak kreditor, selaku pihak yang menurut UUHT mendapatkan hak istimewa yaitu berupa hak menjual atas kekuasaan sendiri. Apabila kendala tersebut berlanjut, selain merupakan masalah yang merugikan bagi pihak bank, juga dapat menghambat pengembalian dana pinjaman yang sangat dibutuhkan untuk percepatan pembangunan ekonomi. Permasalah ini layak untuk diteliti lebih lanjut yang tujuannya untuk mengetahui kepastian hukum pemenuhan hak kreditor dalam eksekusi objek jaminan hak tanggungan melalui parate eksekusi.

\section{B. Metode Penelitian}

Penelitian ini merupakan penelitian yuridis normatif, dengan pendekatan terhadap asas hukum dan pendekatan sinkronisasi hukum. Sifat penelitiannya adalah deskriptif, maksudnya bahwa penelitian ini difokuskan untuk mendeskripsikan kepastian hukum pemenuhan hak kreditor dalam eksekusi objek jaminan hak tanggungan melalui parate eksekusi. Sumber data penelitian yang diambil dalam penelitian ini adalah data sekunder, baik bahan hukum primer, bahan hukum sekunder, maupun bahan hukum tersier, sedangkan metode pengumpulan data yang digunakan adalah metode studi dokumen (studi literatur). Data yang terkumpul, selanjutnya dianalisis dengan menggunakan analisis kualitatif. 


\section{Hasil Penelitian dan Analisis}

\section{Konsep yuridis parate eksekusi}

Perjanjian kredit sering menimbulkan masalah dalam praktik, antara lain karena debitor cidera janji (wanprestasi) untuk melunasi hutangnya kepada kreditor (pihak bank). Terkait dengan masalah ini, kreditor sering kali mengalami kesulitan untuk memperoleh pelunasan kreditnya, dan jika ditempuh dengan cara gugatan melalui pengadilan, maka memerlukan waktu yang lama dan biaya yang cukup banyak, walaupun dalam proses beracara di pengadilan menganut asas sederhana, cepat dan biaya ringan. Oleh karena itu, biasanya pihak kreditor (bank) menempuh cara lain melalui parate eksekusi atau mengeksekusi sendiri/langsung (melelang) agunan tanpa campur tangan pengadilan

Pengertian parate eksekusi adalah melakukan sendiri eksekusi tanpa bantuan atau campur tangan pengadilan atau hakim (Sibarani 2001: 5). Menurut Subekti (1989: 42), dikatakan bahwa parate eksekusi adalah menjalankan sendiri atau mengambil sendiri apa yang menjadi haknya (dalam arti tanpa perantaraan hakim), sedangkan menurut Sudarsono (2007: 39) dikatakan bahwa parate eksekusi adalah pelaksanaan langsung tanpa melalui proses pengadilan; eksekusi langsung yang biasa dilakukan dalam masalah gadai sesuai dengan ketentuan yang tercantum dalam perjanjian.

Pemberian kewenangan mengenai parate eksekusi ini didasarkan atas doktrin, yang antara lain menyatakan bahwa suatu perjanjian yang pasti atau tidak telah mengandung sengketa seperti piutang yang telah pasti (fixed loan). Hal seperti ini sudah dapat dilaksanakan sendiri oleh pihak yang berkepentingan tanpa campur tangan pengadilan, tetapi dalam perkembangan selanjutnya, pengertian parate eksekusi menjadi kabur sebagai akibat dari adanya putusan pengadilan yang menerapkan ketentuan eksekusi grosse akta dalam sengketa parate eksekusi. Menurut doktrin, parate eksekusi ini adalah penjualan yang berada di luar hukum acara dan tidak diperlukan adanya penyitaan, tidak melibatkan juru sita, kesemuanya diselesaikan seperti orang yang menjual sendiri barangnya di depan umum (Sri Soedewi Masjchoen Sofyan 1981: 33). 
Memperhatikan ketentuan yang terdapat dalam KUHPerdata, maka berdasarkan Pasal 1178 ayat (2) ditentukan bahwa namun diperkenankanlah kepada si berpiutang hipotek pertama untuk, pada waktu diberikannya hipotek, dengan tegas minta diperjanjikan bahwa, jika uang pokok tidak dilunasi semestinya, atau jika bunga yang terhutang tidak dibayar, ia secara mutlak akan dikuasakan menjual persil yang diperikatkan dimuka umum, untuk mengambil pelunasan uang pokok, maupun bunga serta biaya, dari pendapatan penjualan itu. Berdasarkan ketentuan ini dapat diketahui bahwa undang-undang memberikan kepada pemegang hipotek pertama untuk menjual langsung atas kekuasaan sendiri barang objek hipotek, tanpa melalui pengadilan.

Dapat diperhatikan pula ketentuan yang terdapat dalam Pasal 6 UU No. 4 Tahun 1996, yang menentukan bahwa apabila debitor cidera janji, pemegang hak tanggungan pertama mempunyai hak untuk menjual objek hak tanggungan atas kekuasaan sendiri melalui pelelangan umum, serta mengambil pelunasan piutangnya dari hasil penjualan tersebut. Maksud ketentuan ini memberikan hak bagi pemegang hak tanggungan untuk melakukan parate eksekusi, sehingga pemegang hak tanggungan tidak perlu memperoleh persetujuan saja dari pemberi hak tanggungan, tetapi juga tidak perlu meminta penetapan dari pengadilan setempat dimana objek hak tanggungan berada, apabila akan melakukan eksekusi atas objek hak tanggungan yang menjadi jaminan hutang debitor dalam hal debitor cidera janji atau wanprestasi. Pemegang hak tanggungan dapat langsung datang dan meminta kepada Kepala Kantor Lelang untuk melakukan pelelangan atas objek hak tanggungan yang bersangkutan, karena kewenangan pemegang hak tanggungan pertama merupakan kewenangan yang diberikan oleh undang-undang (kewenangan yang dimiliki demi hukum), maka kepala kantor lelang negara harus menghormati dan mematuhi kewenangan tersebut.

Dalam penjelasan Pasal 6 UU No. 4 Tahun 1996, disebutkan bahwa hak untuk menjual objek hak tanggungan atas kekuasaan sendiri merupakan salah satu perwujudan dari kedudukan diutamakan yang dipunyai oleh pemegang hak tanggungan atau pemegang hak tanggungan pertama dalam hal terdapat lebih dari satu pemegang hak tanggungan. Hak tersebut didasarkan pada janji yang diberikan 
oleh pemberi hak tanggungan bahwa apabila debitur cidera janji, pemegang hak tanggungan berhak untuk menjual objek hak tanggungan melalui pelelangan umum tanpa memerlukan persetujuan lagi dari pemberi hak tanggungan dan selanjutnya mengambil pelunasan piutangnya dari hasil penjualan itu lebih dahulu dari pada kreditor-kreditor yang lain. Sisa hasil penjualan tetap menjadi hak pemberi hak tanggungan. Dengan demikian dapat dikatakan bahwa hak untuk menjual objek hak tanggungan atas kekuasaan sendiri merupakan salah satu perwujudan dari kedudukan diutamakan yang dimiliki oleh pemegang hak tanggungan, atau oleh pemegang hak tanggungan pertama dalam hal terdapat lebih dari satu pemegang hak tanggungan.

\section{Parate eksekusi sebagai hak kreditor}

Parate eksekusi merupakan kewenangan yang diberikan oleh undangundang kepada salah satu pihak (dalam hal ini kreditor) untuk melaksanakan isi perjanjian, jika pihak lain (debitor) cidera janji atau wanprestasi terhadap pelaksanaan isi perjanjian. Landasan dasar pemberian hak parate eksekusi bagi kreditor adalah perjanjian yang dilakukan antara pihak debitor dengan kreditor yang isinya menyerahkan objek hak milik atas harta debitor kepada kreditor sebagai jaminan atas pelunasan terhadap utang debitor kepadanya.

Dasar pemikiran lainnya bahwa parate eksekusi merupakan bentuk pelaksanaan hak kreditor berdasarkan asas moral yang baik. Berdasarkan asas moral tersebut, kreditor memiliki hak untuk melakukan eksekusi terhadap objek jaminan. Hal ini disebabkan debitor telah menjanjikan bendanya sebagai objek jaminan dalam perjanjian kredit antara kreditor dengan debitor. Perjanjian jaminan ada (timbul) karena diperjanjikan, dalam hal ini debitor berjanji apabila debitor wanprestasi kreditor dapat mengeksekusi objek jaminan yang dijadikan agunan kredit.

Berdasarkan landasan etis dan kesakralan suatu perjanjian seperti yang pernah dikemukakan Grotius, bahwa dengan acuan dasar hukum kodrat ia mengintroduksikan maksim hukum Romawi Kuno asas "pacta sunt servanda", yang artinya "janji itu mengikat". Konsep "pacta sund servanda" tersebut kemudian menjadi konsep dasar atau basis suci (hallowed basis) teori hukum 
perjanjian klasik. Grotius juga mengemukakan "promisorum implendorum obligation" maksudnya, "kita harus memenuhi janji kita". Dalam teori kontraknya Grotius juga mengemukakan "the theory of the inherent moral force of a promise made as such, came to prevail", maksudnya kekuatan mengikat dari perjanjian adalah tanggung jawab moral dari para pembuatnya (Pound 1954: 146).

Dasar pemikiran perlindungan hukum terhadap hak milik kreditor, juga dilandasi aliran hukum alam dari Hugo De Groot sebagaimana dikutip Huijbers (1982: 60), telah merumuskan empat norma dasar dalam hukum alam yaitu:

a. Prinsip ku punya dan kau punya. Milik orang lain harus dijaga, demikian pula jika barang-barang yang dipinjam membawa untung, untung tersebut harus diganjar.

b. Prinsip kesetiaan pada janji.

c. Prinsip ganti rugi, yakni jika kerugian itu disebabkan karena kesalahan orang lain.

d. Prinsip perlunya hukuman karena pelanggaran atas hukum alam dan hukum lainnya.

Prinsip utama pada hak milik kreditor adalah bahwa seseorang yang memiliki benda dari kepunyaan sendiri mendapatkan kepemilikannya kembali berupa hak alamiah. Hak perlu dilindungi agar pemilik dapat menggunakan dan menikmati hak-hak tersebut, baik secara moral maupun ekonomi. Pengambilan dengan tidak memberikan kompensasi bagi pemiliknya adalah suatu tindakan yang tidak dapat dibenarkan karena melanggar ajaran moral yang baik. Dalam ajaran moral biasanya diwujudkan dalam doktrin jangan mencuri atau jangan mengambil apa yang bukan milikmu (Sardjono 2006: 26).

Pendapat Aquinas menyatakan kebaikan (goodness) dan kebahagiaan (happiness) sebagai tujuan akhir dari semua tindakan manusia merupakan landasan moral bagi hukum positif (Aquinas t.t.: 609-613). Dengan demikian, terdapat kaitan yang sangat erat antara hukum moral dengan hukum positif, dalam arti bahwa hukum positif harus selaras dengan moral. Hukum harus membantu manusia berkembang sesuai dengan kodratnya, menjunjung keluhuran martabat manusia, bersifat adil, menjamin kesamaan dan kebebasan, memajukan kepentingan dan kesejahteraan umum. 
Hubungan hukum alam dengan hukum positif biasanya dirumuskan dalam bentuk hak. Hak adalah sesuatu yang diberikan kepada orang lain atas dasar prinsip kesamaan. Sesuatu dapat menjadi hak seseorang melalui dua cara, pertama melalui kodratnya yang disebut hak kodrati. Hak kodrati sebagaimana diatur oleh hukum alam bersumber dari Tuhan. Kedua, sesuatu dapat menjadi hak seseorang melalui perjanjian atau persetujuan dengan orang lain, baik persetujuan antar individu maupun persetujuan publik. Hak yang kedua ini disebut hak positif dan diatur di dalam hukum positif.

Merujuk pada pandangan hukum Kaum Skolastik, seperti Thomas Aquinas yang membagi hukum ke dalam 4 golongan, yaitu: (a) lex aeterna yang merupakan rasio Tuhan yang mengatur segala hal dan merupakan sumber dari segala hukum, (b) lex divina sebagai bagian dari rasio Tuhan yang dapat ditangkap oleh manusia berdasarkan wahyu yang diterimanya, (c) lex naturalis atau hukum alam yang merupakan penjelmaan lex aeterna di dalam rasio manusia, dan (d) lex positivis, sebagai hukum yang berlaku dan merupakan pelaksanaan dari hukum alam oleh manusia, maka sebuah perjanjian pada hakikatnya juga merupakan penjelmaan rasio Tuhan yang terdapat dalam rasio manusia (Lili Rasjidi dan Ira Tania Rasjidi 2001: 47).

Prinsip-prinsip agama dan moralitas adalah bagian inheren dari sebuah perjanjian. Sejarah perjalanan teori perjanjian mencatat bahwa Teori Hukum Klasik yang menjunjung tinggi asas kebebasan berkontrak dalam perjalanannya menuai beragam kritik, karena kebebasan berkontrak bukanlah kebebasan tanpa batas. Ada sejumlah pembatasan terhadap kebebasan berkontrak yang dilakukan baik melalui peraturan perundang-undangan maupun putusan pengadilan. Dalam sistem hukum modern dewasa ini, kebebasan berkontrak tidak hanya dibatasi larangan-larangan yang diciptakan peraturan perundang-undangan (statutory prohibition), tetapi juga oleh extra legal standard (Khairandy 2004: 125). Extra legal standard merupakan standar yang berkaitan dengan agama, moral dan keadilan. Melalui standar tersebut, maka perjanjian tidak semata-mata dipandang sebagai hasil kesepakatan atau kehendak bebas para pihak untuk saling 
mengikatkan diri, tetapi perjanjian harus dikaitkan dengan prinsip-prinsip agama, moral dan keadilan.

Asumsi dasar kebebasan berkontrak adalah para pihak memiliki posisi tawar (bargaining position) yang seimbang, tetapi dalam kenyataannya para pihak seringkali tidak memiliki posisi tawar yang sesuai dengan asumsi dasar tersebut. Akibatnya, pelaksanaan prinsip kebebasan berkontrak justru seringkali melahirkan ketidakadilan, pihak yang memiliki posisi tawar yang kuat akan cenderung menguasai pihak yag memiliki posisi tawar yang lebih lemah. Dalam kondisi dan situasi seperti itu, negara harus memainkan peran sebagai provider (penjamin) kelangsungan perjanjian, sebagai regulator, pengatur dan perumus aturan main perjanjian dan negara harus memainkan peran sebagai umpire (pengawas/wasit) untuk merumuskan standar yang adil dalam perjanjian (Friedman 1971: 3).

Ajaran negara kesejahteraan (welfare state) mewajibkan pemerintah untuk memainkan banyak peran dan menyiapkan banyak pengaturan yang berhubungan dengan upaya peningkatan kesejahteraan rakyat. Pengaturan tersebut meliputi pemberian santunan bagi mereka yang tidak mampu bekerja, jaminan akan terpenuhinya kebutuhan kehidupan yang layak, seperi pangan, kesehatan, pendidikan dan lain sebagainya. Banyaknya tanggung jawab dan tugas yang dibebankan kepada negara dalam upaya peningkatan kesejahteraan rakyat merupakan salah satu asas negara kesejahteraan modern (Nugraha 2002: 19). Indonesia adalah negara yang menganut ajaran negara kesejahteraan (welfare state). Adanya pengakuan dan perlindungan atas hak-hak sosial dan ekonomi rakyat dalam konstitusi negara, telah menempatkan UUD 1945 selain sebagai konstitusi politik sekaligus juga sebagai konstitusi ekonomi yang berkarakter dan mengandung ajaran negara hukum kesejahteraan (Ashshiddiqie 1998: 1).

Perjanjian adalah salah satu sendi yang paling utama dalam Hukum Perdata. Berbeda dengan Hukum Pidana dan Hukum Tata Negara, dalam Hukum Perdata, peraturan-peraturan hukum yang tercipta tergantung pada tindakan orang per orang yang berkepentingan (individueele rechtsvorming) dan yang tidak diadakan oleh alat-alat perlengkapan negara yang berwajib membentuk udangundang (Prodjodikoro 1992: 36). Bahkan menurut van Apeldoorn (1986: 167), 
perjanjian adalah faktor yang membantu pembentukan hukum, dan menurut Lemaire sebagaimana dikutip Sudikno Mertokusumo (1991: 97), mengatakan bahwa perjanjian adalah determinan hukum. Perjanjian hakikatnya adalah hukum dan sekaligus sumber hukum.

Sudikno Mertokusumo (1991: 98), menyatakan bahwa perjanjian merupakan suatu perbuatan hukum antara dua pihak atau lebih berdasarkan kata sepakat untuk menimbulkan akibat hukum Dua pihak atau lebih tersebut bersepakat untuk menentukan peraturan atau kaidah atau hak dan kewajiban. Kesepakatan ini penting untuk menimbulkan akibat hukum, menimbulkan hak dan kewajiban, dan kalau kesepakatan tersebut dilanggar, maka ada akibat hukum yang dapat dikenakan kepada pelanggar. Dengan demikian ada 4 unsur penting yang harus ada dalam sebuah perjanjian, yaitu: (a) adanya perbuatan hukum; (b) adanya dua pihak atau lebih; (c) adanya kata sepakat; dan (d) adanya akibat hukum yang disepakati/dikehendaki oleh para pihak.

Sudikno Mertokusumo (1991: 98) mengatakan bahwa perjanjian memiliki beberapa unsur, yaitu: unsur essensialia, naturalia, dan accidentalia. Unsur essentialia adalah unsur yang mutlak harus ada agar perjanjian itu sah. Unsurunsur yang termasuk kategori essentialia adalah adanya kata sepakat atau persesuaian kehendak, kecakapan para pihak, obyek tertentu dan kausa atau dasar yang halal. Unsur naturalia adalah unsur yang lazimnya melekat pada perjanjian meskipun tanpa diperjanjikan secara khusus, misalnya pada perjanjian jual beli, penjual harus menjamin pembeli terhadap cacat-cacat yang tersembunyi. Unsur accidentalia adalah unsur yang harus dimuat atau disebut secara tegas dalam perjanjian, misalnya mengenai tempat tinggal yang dipilih.

Pasal 1320 KUH Perdata mengatur bahwa sebuah perjanjian akan dianggap sah bila memenuhi syarat-syarat umum sebagai berikut:

a. Adanya kesepakatan mereka yang mengikatkan diri. Sepakat dalam hal ini adalah sepakat yang bebas, tanpa unsur paksaan, penipuan atau kekhilafan. Jika sebuah kesepakatan mengandung unsur-unsur tersebut, maka perjanjian tersebut dapat dimintakan pembatalannya. 
b. Para pihak cakap untuk membuat suatu perikatan. Maksudnya adalah para pihak sudah dewasa dan sehat pikirannya, sehingga dianggap cakap menurut hukum.

c. Adanya suatu hal tertentu yang diperjanjikan. Artinya, perjanjian yang dilakukan hanya mengenai barang yang dapat menjadi obyek perjanjian dan diperbolehkan oleh undang-undang.

d. Adanya suatu sebab yang halal. Artinya, suatu perjanjian yang dibuat tidak boleh bertentangan dengan kesusilaan dan ketertiban umum.

Sebagai sebuah perbuatan hukum, perjanjian melahirkan hak bagi para pihak yang terlibat di dalamnya. Menurut Fitzgerald sebagaimana dikutip Satjipto Rahardjo (2002: 96), mengatakan bahwa salah satu ciri dari suatu hak adalah selalu berkorelasi dengan kewajiban. Hak melahirkan kewenangan, dan kewenangan melahirkan kekuasaan. Dari konsep ini maka hak adalah kehadiran dari kewajiban di pihak lain dan pertanggungjawaban adalah kehadiran dari kekuasaan di pihak lain. Seseorang yang mempunyai hak maka ia mempunyai kewajiban dan pada akhirnya ia mempunyai tanggung jawab. Dengan demikian, tanggung jawab dapat dikenakan kepada seseorang yang melakukan perbuatan hukum karena perbuatan hukum melahirkan kewajiban hukum. Seseorang dapat dikategorikan masuk dalam melakukan perbuatan hukum apabila ia mempunyai status yang jelas dan pasti dalam perbuatan hukum yang bersangkutan.

Eksistensi pengadilan sebagai lembaga yang berfungsi menyelenggarakan proses peradilan dalam menerima, memeriksa dan mengadili sengketa dalam masyarakat, tugas-tugasnya diwakili oleh hakim. Dengan demikian, kepercayaan masyarakat terhadap hukum serta institusi peradilan di negara ini ditentukan oleh kredibilitas dan profesionalitas hakim dalam menjalankan tugasnya menyelesaikan sengketa serta menegakkan peradilan. Para hakim dituntut untuk secara total melibatkan dirinya pada saat membuat putusan, bukan hanya mengandalkan kemahirannya mengenai perundang-undangan.

Pandangan lain yang sejalan adalah pendapat Mochtar Kusumaatmadja, yang telah berupaya mengembangkan Teori Hukum Pembangunan dengan dilandasi paradigma yang dipadukan dengan pola nilai hidup dalam masyarakat. 
Menurut Mochtar Kusumaatmadja dikatakan bahwa terhadap bidang-bidang hukum yang behubungan dengan masalah kehidupan budaya dan spiritual kemasyarakatan untuk sementara dibiarkan atau pembaharuannya dilakukan secara hati-hati dengan mempertimbangkan berbagai aspek. Untuk bidang hukum yang relatif netral, seperti dalam lapangan hukum perikatan, hukum perseroan, hukum perniagaan dapat lebih dikedepankan, termasuk dalam bidang hukum jaminan kebendaan.

Teori Hukum Pembangunan mendukung analisis permasalahan yang diteliti, dengan alasan bahwa:

a. Teori ini mendefinisikan hukum bukan saja hanya sebagai norma dan asasasas, tetapi mencakup juga lembaga dan proses yang diperlukan untuk mewujudkan hukum itu dalam kenyataan.

b. Dapat mengadopsi perkembangan hukum masyarakat sesuai dengan tuntutan zaman, dengan konsepnya yang dikenal dengan nama Hukum sebagai Sarana Pembangunan Masyarakat.

c. Permasalahan yang diteliti menyangkut hukum jaminan kebendaan yang merupakan bagian dari hukum ekonomi yang bersifat netral, sedangkan yang tidak netral adalah hukum keluarga seperti hukum perkawinan dan hukum waris.

d. Era reformasi menuntut adanya perubahan-perubahan dalam masyarakat yang dapat menimbulkan ketegangan-ketegangan dan deviasi-deviasi karena berbagai pengaruh, sehingga dengan diterapkannya teori ini, akan melahirkan kembali keselarasan, keserasian dan keseimbangan dalam masyarakat.

Dengan demikian teori ini dapat membantu mengarahkan terhadap pendekatan pemecahan masalah dalam penelitian ini.

Berdasarkan uraian sebelumnya terlihat bahwa parate eksekusi merupakan hukum yang netral, seperti pendapat Mochtar Kusumaatmadja, bahwa dalam pembangunan hukum harus dipilah-pilah hukum netral dan tidak netral. Hukum jaminan merupakan hukum netral. Dihubungkan dengan pendapat Mochtar, untuk hukum netral harus berdasarkan asas universal (hukum itu berlaku universal dan bersifat abadi, artinya bahwa hukum itu berlaku dimana pun juga dan pada saat 
kapan pun), sehingga dalam hukum perjanjian dan hukum jaminan agar tidak terkucil harus dapat diterima oleh negara lain.

Di sisi lain bahwa dari aspek yuridis, terhadap perjanjian yang dibuat secara sah, akan mengikat para pihak sebagai Undang-undang (diatur pada Pasal 1338 KUH Perdata). Dalam hal ini perjanjian yang dibuat para pihak meliputi beberapa asas yang harus di penuhi yaitu: pacta sund servanda yang artinya perjanjian yang telah dibuat harus ditepati, dan asas itikad baik bahwa perjanjian harus dilaksanakan dengan itikad baik terutama terhadap pelaksanaan isi dari perjanjian yang telah dibuat bersama tersebut.

Menurut hemat penulis pelaksanaan parate eksekusi merupakan suatu bentuk perlindungan bagi pihak kreditor agar dalam proses pemberian kredit, khususnya setelah kredit tersebut direalisasi dan telah diterima debitor, pihak kreditor tidak dirugikan oleh pihak debitor yang melakukan wanprestasi terutama dalam melaksanakan perjanjian kredit, juga untuk memberikan kepastian terhadap pengembalian kredit yang telah diberikan kreditor kepada debitor.

Pelaksanaan parate eksekusi yang akan dilakukan oleh pihak kreditor, dilaksanakan dengan bantuan KPKNL di wilayah domisili tempat perjanjian kredit tersebut dibuat. Dalam melaksanakan lelang, KPKNL berpedoman selain kepada aturan pada UUHT juga berpedoman kepada peraturan lelang. Peraturan Lelang Pasal 42 ayat (4) menegaskan bahwa berita acara lelang yang telah diberi bentuk sebagai grosse (memakai kata-kata "Demi Keadilan Berdasarkan Ketuhanan YME" pada bagian kepala berita acara), sama kekuatannya dengan grosse akta hipotik dan grosse akta pengakuan hutang.

Pemberian Hak Tanggungan didahului dengan janji untuk memberikan Hak Tanggungan sebagai jaminan pelunasan hutang tertentu, yang dituangkan di dalam dan merupakan bagian tak terpisahkan dari perjanjian hutang-piutang yang bersangkutan, atau perjanjian lainnya yang menimbulkan hutang tersebut. Sesuai dengan sifat accessoir dari Hak Tanggungan, pemberiannya harus merupakan ikutan dari perjanjian pokok, yaitu perjanjian yang menimbulkan hubungan hukum hutang-piutang yang dijamin pelunasannya. Menurut hemat penulis, perjanjian yang menimbulkan hubungan hutang-piutang tersebut, dapat dibuat 
dengan akta di bawah tangan atau dibuat dengan akta otentik yang bergantung pada ketentuan hukum yang mengatur materi perjanjian itu.

Janji-janji untuk memberikan Hak Tanggungan sebagai pelunasan hutang disebut dengan tahap pemberian Hak Tanggungan, dengan dibuatnya APHT oleh Pejabat Pembuat Akta Tanah yang didahului dengan hutang piutang yang dijamin; dan tahap pendaftaran oleh Kantor Pertanahan, yang merupakan saat lahirnya Hak Tanggungan yang telah dibebankan. Pemasangan APHT diatur dalam Pasal 11 ayat (1) UUHT, dimana pasal ini mengatur tentang hal-hal yang wajib dicantumkan dalam APHT. Selanjutnya Pasal 11 ayat (2) UUHT mengatur tentang dicantumkannya janji-janji dalam APHT yang akan dibuat.

Pemberian Hak Tanggungan, secara khusus diatur dalam Pasal 11 ayat (1) UUHT, yang menetapkan isi yang sifatnya wajib untuk sahnya Akta Pemberian Hak Tanggungan (APHT). Apabila tidak dicantumkan secara lengkap tentang halhal yang disebutkan dalam APHT, maka mengakibatkan akta yang bersangkutan batal demi hukum. Hal-hal yang wajib dicantumkan dalam suatu APHT meliputi:

a. Nama dan identitas pemegang dan pemberi Hak Tanggungan. Maksud dari ketentuan ini menetapkan isi yang sifatnya wajib, untuk sahnya APHT. Tidak dicantumkannya secara lengkap hal-hal yang disebut pada ayat ini dalam APHT mengakibatkan akta yang bersangkutan batal demi hukum.

b. Ketentuan ini juga dimaksudkan untuk memenuhi asas spesialitas dari Hak Tanggungan, baik mengenai subjek, objek maupun hutang yang dijamin. Apabila Hak Tanggungan dibebankan pula pada benda-benda yang merupakan satu kesatuan dengan tanah milik perseorangan atau badan hukum lain daripada pemegang hak atas tanah pemberi Hak Tanggungan adalah pemegang hak atas tanah bersama-sama pemilik benda tersebut.

c. Domisili pihak-pihak sebagaimana dimaksud pada huruf a, dan apabila di antara mereka ada yang berdomisili di luar Indonesia, baginya harus pula dicantumkan suatu domisili pilihan di Indonesia dan dalam hal domisili pilihan itu tidak dicantumkan, kantor PPAT tempat pembuatan APHT dianggap sebagai domisili pilihan yang dipilih; maksudnya dengan dianggapnya kantor PPAT sebagai domisili di Indonesia bagi pihak yang berdomisili di luar negeri 
apabila domisili pilihannya tidak disebut di dalam akta, syarat pencantuman domisili pilihan tersebut dianggap sudah dipenuhi.

1) Penunjukan secara jelas utang atau utang-utang yang dijamin sebagaimana dimaksud dalam Pasal 3 dan Pasal 10 ayat (1); maksudnya penunjukkan utang atau utang-utang yang dijamin sebagaimana dimaksud pada huruf ini meliputi juga nama dan identitas debitor yang bersangkutan.

2) Nilai tanggungan

3) Uraian yang jelas mengenai objek hak tanggungan, meliputi rincian mengenai sertifikat hak atas tanah yang bersangkutan, atau bagi tanah yang belum terdaftar yang sekurang-kurangnya memuat uraian mengenai kepemilikan, letak, batas-batas dan luas tanahnya.

Dengan demikian, hal-hal yang disebutkan di atas harus dicantumkan secara lengkap dalam APHT, sehingga APHT tidak akan batal demi hukum.

Akta Pemberian Hak Tanggungan dapat dicantumkan janji-janji yang sifatnya fakultatif dan tidak mempunyai pengaruh terhadap sahnya APHT. Dimuatnya janji-janji itu dalam APHT yang kemudian didaftar pada Kantor Pertanahan, maka janji-janji tersebut juga mempunyai kekuatan mengikat terhadap pihak ketiga. Janji-janji sebagaimana disebutkan dalam undang-undang (Pasal 11 ayat 2 UUHT), bukan berarti bahwa janji seperti itu boleh diperjanjikan oleh kreditor karena undang-undang menyatakan demikian (atau memberikan kesempatan seperti itu). Undang-undang dalam hal ini hanya mengingatkan saja kepada kreditor akan kemungkinan untuk memperjanjikan janji-janji seperti itu, karena pada asasnya, orang dapat memperjanjikan apa saja, asal tidak bertentangan dengan undang-undang yang bersifat memaksa, kesusilaan dan ketertiban umum.

Bila dikaji kata-kata dalam Pasal 11 ayat (2) UUHT, yang menyatakan: "Dalam APHT dapat dicantumkan janji-janji...", pengertian kata "dapat" dimaksudkan oleh undang-undang adalah memperbolehkan bagi kreditor untuk memperjanjikan klausula berupa janji-janji yang telah ditawarkan sebagaimana yang ditentukan dalam Pasal 11 ayat (2) UUHT kepada kreditor untuk 
memperjanjikan janji-janji tersebut atau tidak. Dengan demikian dapat dilihat bahwa undang-undang memberikan pilihan untuk memperjanjikannya.

Sutan Remy Sjahdeini menyatakan Pasal 11 ayat (2) UUHT bersifat fakultatif dan tidak limitatif, maksudnya karena janji-janji itu boleh dicantumkan atau tidak dicantumkan baik sebagian maupun seluruhnya, sedangkan bersifat tidak limitatif karena dapat pula diperjanjikan janji-janji lain selain dari janji-janji yang telah disebutkan dalam Pasal 11 ayat (2) UUHT.

Janji-janji seperti yang telah disebutkan, dalam praktiknya hampir dapat dikatakan selalu diperjanjikan oleh kreditor, sehingga untuk memudahkan para pihak janji-janji itu sudah dicetak dalam blanko formulir APHT, maka atas dasar apa yang disebutkan dalam Pasal 11 ayat (2) UUHT, klausula itu atas sepakat para pihak boleh dihapus dari blanko yang bersangkutan. Dalam hal ini, menurut hemat penulis apabila terdapat klausula baku yang telah dibuat oleh pihak kreditor, apabila tidak disetujui oleh debitor maka pihak debitor dan kreditor dapat melakukan peninjauan ulang dan memperbaiki klausula-klausula tersebut, untuk disepakati sebagai sebuah perjanjian yang mengikat bagi kedua belah pihak.

Apabila antara kreditor dengan debitor sepakat untuk menandatangani APHT, maka janji-janji yang dimaksudkan merupakan perwujudan keseriusan dan itikad baik dari debitor, dengan janji-janji tersebut maka apabila debitor wanprestasi, kreditor diberi hak atau kewenangan sebagaimana yang diperjanjikan. Hal tersebut demi dan untuk melindungi kepentingan kreditor ketika debitor wanprestasi, dan tidak segera melunasi hutangnya kepada kreditor. Hak atau kewenangan sebagaimana yang diperjanjikan para pihak tersebut, mengarah kepada pemenuhan unsur kepastian hukum. Kepastian hukum terhadap hak kreditor dapat dilihat sebagai berikut: kepastian hukum (legal certainty atau certain in law), antara lain ditemukan dalam istilah "certain" yang didalamnya juga merumuskan pengertian kepastian dalam hukum (certain in law).

Black's law Dictionary (1991: 254) merumuskan pengertian "certain” sebagai berikut: "Certain. Ascertained: precise; identified; settled; exact; definitive; clearly known; unambiguous; or, in law, capable of being identified or made known, without liability to mistake or ambiguity, from data already given. 
Free from about.Definisi ini menunjukkan bahwa dalam pengertian kepastian (certain), juga tercakup pengertian kepastian dalam hukum (certain in law).

\section{Kepastian hukum hak kreditor melalui parate eksekusi objek jaminan hak tanggungan}

Kepastian hukum merupakan salah satu asas essensial dalam negara hukum. Budiono Kusumohamidjojo (1999: 150) berpendapat bahwa kepastian hukum nyaris merupakan syarat mutlak bagi suatu negara hukum modern dan demokratis. Hal ini berarti bahwa kepastian hukum sebagai salah satu tujuan hukum mengandung arti adanya konsistensi dalam penyelenggaraan hukum suatu negara. Konsistensi tersebut diperlukan sebagai acuan atau patokan bagi perilaku manusia sehari-hari dalam berhubungan dengan manusia lainnya. Dengan demikian dapat dikatakan bahwa fungsi kepastian hukum tersebut, antara lain untuk memberikan patokan bagi perilaku yang tertib, damai dan adil. Kepastian hukum merupakan salah satu tujuan utama dari hukum, selain kemanfaatan atau kegunaan dan keadilan. Bagi penganut aliran positivisme hukum (legal positivisme), hukum tidak lain bertujuan untuk mencapai kepastian hukum. Sudikno Mertokusumo (2003: 167), menyatakan bahwa dalam sejarah filsafat hukum, dikenal ajaran legisme yang pandangannya sangat positivistik atau legalistikPaham legisme memandang undang-undang sebagai satu-satunya sumber hukum, di luar undang-undang tidak ada hukum. Paham ini muncul pada abad pertengahan sejalan dengan munculnya gerakan kodifikasi hukum Eropa, yang pada dasarnya bertujuan untuk menjamin kepastian hukum.

Gustav Radbruch secara tidak langsung menyinggung tentang kepastian hukum ketika membicarakan cita hukum. Radbruch menyebut tiga cita hukum, yang pertama adalah keadilan. Untuk mengisi cita keadilan dengan isi kongkret, harus melihat pada kegunaannya sebagai unsur kedua dari cita hukum. Pengertian kegunaan hanya dapat dijawab dengan menunjuk pada konsepsi-konsepsi yang berbeda tentang negara dan hukum. Untuk melengkapi formalitas keadilan dan relativitas kegunaan, perlu juga memasukkan ketertiban sebagai unsur ketiga dari cita hukum. Radbruch menyatakan kegunaan menuntut adanya kepastian hukum, hukum harus pasti (Friedman 1994: 43). Tuntutan akan keadilan dan kepastian 
dengan demikian merupakan bagian yang tetap dari cita hukum, serta berada di luar pertentangan-pertentangan bagi pandangan politik dan kegunaan memberi unsur relativitas, tidak hanya kegunaan yang bersifat relatif, tetapi hubungan antara tiga unsur dari cita hukum tersebut, juga bersifat relatif.

Periode hukum alam menekankan pada unsur keadilan dan mencoba menjadikannya sebagai unsur yang pokok, dan positivisme hukum hanya memandang penting kepastian hukum dan mengabaikan keadilan maupun kegunaan. Terkait dengan kepastian hukum, Arif Sidharta mengemukakan bahwa asas kepastian hukum mengimplikasikan bahwa warga masyarakat harus bebas dari tindakan pemerintah dan pejabatnya yang tidak dapat diprediksi dan tindakan yang sewenang-wenang (Sidharta 2000: 200). Pemerintah dan para pejabatnya harus terikat dan tunduk pada aturan hukum positif. Semua tindakan pemerintah dan para pejabatnya harus selalu bertumpu pada aturan hukum positif sebagai dasar hukumnya.

Mochtar Kusumaatmadja dan Arief Sidharta (2000: 49-50), juga berbicara tentang kepastian (hukum) dalam kaitan dengan fungsi dan tujuan hukum, yaitu untuk mencapai keteraturan dalam kehidupan manusia dalam masyarakat. Keteraturan menyebabkan orang dapat hidup dengan berkepastian, artinya orang bermasyarakat karena ia dapat mengadakan perhitungan tentang apa yang akan terjadi atau apa yang dapat ia harapkan. Mengenai keteraturan merupakan inti dari kepastian, apabila dihubungkan dengan kepastian penjaga keamanan diri maupun harta milik dapat juga disebut ketertiban. Dihubungkan dengan dunia usaha, kepastian demikian diperlukan karena tanpa kepastian tidak mungkin diadakan perhitungan-perhitungan yang diperlukan dalam dunia usaha.

Merujuk pada pernyataan di atas, diketahui bahwa kepastian bermakna sama dengan keteraturan, dengan kata lain dalam keteraturan terkandung kepastian (hukum). Hal ini terlihat pada pernyataan sebagai berikut: "Dikatakan bahwa tujuan hukum adalah terpelihara dan terjaminnya keteraturan (kepastian) dan ketertiban. Tanpa keteraturan dan ketertiban, kehidupan manusia yang wajar memang tidak mungkin. Orang tidak dapat mengadakan usaha mengembangkan 
bakatnya tanpa adanya kepastian dan keteraturan" (Kusumaatmadja dan Sidharta 2000: 50).

Menurut hemat penulis kepastian hukum sebagai salah satu tujuan hukum, harus seimbang dengan tujuan hukum lainnya, antara lain keadilan dan kemanfaatan. Demikian juga sebaliknya, keadilan dan kemanfaatan harus selalu berada dalam keseimbangan dengan kepastian. Kepastian hukum memiliki peran yang penting dalam rangka penegakan hukum. Penegakan hukum yang dimaksud adalah upaya untuk membuat hukum dapat berfungsi, beroperasi dan terwujud secara kongkret. Dengan demikian, istilah penegakan hukum dapat diartikan sebagai fungsionalisasi hukum atau operasionalisasi hukum atau konkretisasi hukum termasuk dalam bidang hukum perkreditan. Hukum dapat dibuat menjadi berfungsi, beroperasi (bekerja sehingga terwujud secara konkret, yang memerlukan proses. Dengan demikian penegakkan hukum merupakan suatu proses bekerja dan berfungsinya hukum, oleh aparat hukum terhadap perilaku-perilaku yang secara formal material berlawanan dengan norma-norma hukum.

Kepastian hukum merupakan perlindungan yustisiabel terhadap tindakan sewenang-wenang, yang berarti bahwa seseorang akan dapat memperoleh sesuatu yang diharapkan dalam keadaan tertentu. Masyarakat mengharapkan adanya kepastian hukum, karena dengan adanya kepastian hukum, masyarakat akan lebih tertib. Hukum bertugas menciptakan kepastian hukum untuk tujuan ketertiban masyarakat.

Pada kepastian hukum, umumnya terkait dengan hukum tertulis. Dengan kata lain, hukum tertulis lebih menjamin kepastian hukum dibandingkan dengan hukum tidak tertulis, tetapi hukum tertulis bukanlah satu-satunya sumber hukum. Kepastian hukum perlu diselaraskan dengan tujuan hukum lainnya, antara lain keadilan dan kemanfaatan. Dengan demikian, dalam penerapan hukum tertulis juga perlu diperhatikan hukum yang hidup dan berkembang dalam masyarakat (living law).

Dalam suatu sistem hukum, terdapat suatu susunan hirarki peraturan perundang-undangan yang bertingkat dan berjenjang. Secara materiil, di dalamnya terdapat struktur norma. Norma yang lebih tinggi menjadi pedoman terhadap 
norma yang lebih rendah. Struktur norma tersebut bukan merupakan derivasi dari fakta, sehingga ketidakcocokan suatu norma harus dikembalikan pada dogma yang lebih tinggi (Kelsen 1995: 55).

Norma secara umum dibedakan antara norma hukum publik dan norma hukum privat (Purbacaraka 1989: 7-10). Tujuan penormaan dalam tata urutan perundang-undangan adalah untuk menjamin adanya kepastian hukum atas sikap tindak yang adil dan benar di dalam hubungan warga masyarakat. Beberapa asas penting dalam mewujudkan kepastian hukum antara lain:

a. Asas lex superiori derogate leg inferiori yang berarti bahwa peraturan perundang-undangan yang lebih rendah tingkatannya (berada di bawahnya);

b. Asas lex posterior derogate legi prori yang berarti peraturan perundangundangan yang baru mengalahkan peraturan perundang-undangan yang telah lama;

c. Asas lex specialis derogate legi generale yang berarti peraturan perundangundangan yang bersifat khusus mengalahkan peraturan perundang-undangan yang bersifat umum; dan

d. Asas non-retroaktif yang berarti asas yang melarang adanya peraturan perundang-undangan yang berlaku surut.

Peraturan perundang-undangan dapat memberikan kepastian hukum lebih tinggi daripada hukum kebiasaan, hukum adat maupun hukum yurisprudensi. Namun, perlu diketahui bahwa kepastian hukum peraturan prundang-undangan tidak semata-mata diletakkan pada bentuknya yang tertulis (geschreven, written). Untuk benar-benar menjamin rechtszekerheid atau legal certainty (kepastian hukum), maka peraturan perundang-undangan selain haus memenuhi syarat-syarat formal, juga harus memenuhi syarat-syarat lain, yaitu:

a. Jelas dalam perumusannya (unambiguous); dan

b. Konsisten dalam perumusannya, baik secara intern maupun ektern. Konsisten secara intern mengandung makna bahwa dalam peraturan perundang-undangan yang sama harus terpelihara hubungan sistemik antara kaidah-kaidahnya, kebakuan susunan dan bahasa. Konsistensi secara ekstern adalah adanya hubungan "harmonisasi" antara berbagai peraturan perundang-undangan. 
Pelaksanaan hukum dalam praktik, sering terjadi debitor melakukan perlawanan terhadap parate eksekusi yang secara hukum merupakan hak dari kreditor. Sebagai landasan dasar pelaksanaan terhadap hak parate eksekusi kreditor yaitu perjanjian yang secara hukum harus dilaksanakan berdasarkan asas pacta sund servanda dan itikad baik, sehingga apabila debitor melakukan perlawanan, dalam hal ini debitor telah mengingkari janji khususnya dalam pembebanan hak tanggungan.

Akibat perlawanan yang dilakukan debitor, maka hak parate eksekusi kreditor menjadi terganggu, dalam perkembangannya sebelumnya sering terjadi perkara menumpuk di KPKNL karena KPKNL tidak mau melaksanakan hak parate eksekusi kredit, dengan alasan KPKNL tidak mau terlibat dalam permasalahan kreditor karena adanya gugatan debitor.

Perlawanan dari debitor dan adanya keengganan dari beberapa KPKNL untuk melaksanakan hak parate eksekusi kredit, menimbulkan permasalahan baru bagi pihak kreditor dan hal ini telah menimbulkan suatu ketidakpastian hukum kreditor untuk melaksanakan hak parate eksekusi.

\section{Simpulan dan Saran}

\section{Simpulan}

Prinsip-prinsip yang mendasari parate eksekusi sebagai sarana untuk mempercepat pelunasan piutang kreditor adalah prinsip perlindungan hukum bagi pemegang hak jaminan pertama. Perwujudan prinsip perlindungan hukum tersebut, tercermin dalam pelaksanaan parate eksekusi berupa adanya kemudahan, waktu yang cepat, dan biaya yang murah untuk mendapatkan kembali piutang kreditor dibandingkan dengan eksekusi berdasarkan titel eksekutorial. Parate eksekusi melaksanakan prosedur penjualan objek hak jaminan atas kekuasaan sendiri, tanpa didahului sita jaminan dan sita eksekusi serta tanpa fiat pengadilan. Parate eksekusi tidak terlepas dari lembaga jaminan, di mana lembaga ini berfungsi di satu sisi merupakan pemenuhan kebutuhan kreditor (bank) untuk memperkecil resiko dalam penyaluran kredit. Di sisi yang lain jaminan sebagai sarana perlindungan bagi keamanan kreditor melalui kepastian terhadap pelunasan 
utang debitor atau pelaksanaan suatu prestasi oleh debitor atau penjamin debitor, bila debitor tidak mampu menyelesaikan kewajiban-kewajiban berkenaan dengan penyaluran kredit tersebut.

\section{Saran}

Kecepatan dan perkembangan pembangunan ekonomi khususnya pada pembangunan nasional saat ini sangat ditentukan oleh adanya iklim investasi yang baik yang di dalamnya menyangkut kepastian dalam proses pemberian dan pengembalian kredit oleh debitor. Kecepatan dan kepastian pengembalian dana oleh debitor, pada akhirnya akan memudahkan bagi pihak kreditor atau bank untuk memutar kembali dana tersebut bagi kepentingan perputaran perekonomian, oleh sebab itu hukum harus mampu memberikan jaminan kepastian hukum bagi pelaksanaan parate eksekusi bagi jaminan hak tanggungan. 


\section{DAFTAR PUSTAKA}

\section{Buku:}

Aquinas, Thomas. t.th.. The Summa Theologica: On the Essence of Law (edited with an introduction by Anton C. Pegis. The Modern Library.

Bernard Arief Sidharta. 2000. Refleksi tentang Struktur Ilmu Hukum: Sebuah penelitian tentang Fundasi Kefilsafatan dan Sifat Keilmuan Ilmu Hukum sebagai Landasan Pengembangan Ilmu Hukum Nasional Indonesia. Cetakan Kedua. Bandung: Mandar Maju.

Black, Henry Campbell. 1991. Black's Law Dictionary. Sixt Edition. St. PulMinn: West Publishing Co.

Budiono Kusumohamidjojo. 1999. Ketertiban yang Adil: Problematik Filsafat Hukum. Jakarta: Grasindo.

Djuhaendah Hasan. 1996. Lembaga Jaminan Kebendaan Bagi Tanah dan Benda Lain yang Melekat pada Tanah dalam Konsepsi Penerapan Asas Pemisahan Horizontal. Bandung: Citra Aditya Bakti.

Friedman, W.. 1994. Teori \& Filsafat Hukum: Idealisme Filosofis \& Problema Keadilan (Susunan II). Cetakan Kedua. Penterjemah Muhammad Arifin. Jakarta: RajaGrafindo.

Friedman. W.. 1971. The State and The Rule of Law in A Mixed Economy. Steven and Sons. London.

Kelsen. Hans. 1995. Teori Hukum Murni. Dasar-dasar Ilmu Hukum Normatif Sebagai Ilmu Hukum Empirik-Deskriptif. Alih Bahasa Sumardi. Jakarta: Rimdi Press.

Lili Rasjidi dan Ira Tania Rasjidi. 2001. Dasar-dasar Filsafat dan Teori Hukum. Bandung: Citra Aditya Bakti.

Marzuki Usman. 1988. Keuangan Perbankan Indonesia. Jakarta: Infobank-Griya Perbanas.

Mochtar Kusumaatmadja dan B. Arief Sidharta. 2000. Pengantar Ilmu Hukum. Buku I. Bandung: Alumni.

Pound, Roscoe. 1954. Introduction to The Philosophy of Law (Revised edition). New Haven: Yale University Press.

Purnadi Purbacaraka (et.al). 1989. Perundang-undangan dan Yurisprudensi. Bandung: Citra Aditya Bakti.

Ridwan Khairandy. 2004. Itikad Baik dalam Kebebasan Berkontrak. Jakarta: Fakultas Hukum Program Pascasarjana Universitas Indonesia.

Satjipto Rahardjo. 2002. Ilmu Hukum. Bandung: Alumni. 
Subekti, R. 1989. Hukum Acara Perdata. Bandung: Bina Cipta.

Sudarsono. 2007. Kamus Hukum. Jakarta: Rineka Cipta.

Sudikno Mertokusumo. 2003. Mengenal Hukum: Suatu Pengantar. Edisi Kelima. Cetakan Pertama.Yogyakarta: Liberty.

Sri Soedewi Masjchoen Sofwan. 1981. Hukum Perdata: Hukum Benda. Yogyakarta: Liberty.

Sunaryati Hartono. 1991. Politik Hukum Menuju Satu Sistem Hukum Nasional. Bandung: Alumni.

Theo Huijbers. 1982. Filsafat Hukum dalam Lintasan Sejarah. Yogyakarta: Kanisius.

Tim Redaksi Fokusmedia. Perbankan dan Lembaga Penjamin Simpanan: Undang-undang R.I. No. 10 Tahun 1998 tentang Perubahan atas Undang-undang No. 7 Tahun 1992 tentang Perbankan. Bandung. Fokusmedia.

Van Apeldoorn, L. J. 1986. Pengantar Ilmu Hukum. Alih Bahasa Oetarid Sadino. Jakarta: Pradnya Paramita.

Wirjono Prodjodikoro. 1992. Asas Hukum Perdata. Sumur: Bandung.

\section{Laporan Penelitian/Jurnal/Makalah:}

Agus Sarjono. 2004. "Negara Maju vs Negara Berkembang: Studi Mengenai Kemungkinan Perlindungan Pengetahuan Obat-obatan Tradisional Sebagai Kekayaan Intelektual di Indonesia," Disertasi, Jakarta: Pascasarjana Universitas Indonesia.

Adalbert Evers, et.al (ed). 2002. "The Changing Face of Welafare State", 1987, dalam Safri Nugraha, "Future of Welafare State in The Era of Privatitation", Universitas Indonesia Law Journal, Volume 4 Nomor 1 April 2002. Jakarta.

Bachtiar Sibarani. 2001. "Parate Eksekusi dan Paksa Badan", Jurnal Hukum Bisnis. Vol. 15, September.

Bagir Manan. 2004. "Fungsi dan Materi Peraturan Perundang-undangan", Makalah, disajikan pada Penataran Dosen Pendidikan dan Kemahiran Hukum BKS-PTN Bidang Hukum Sewilayah Barat, Tanggal 19 Nopember, Bandar Lampung: Fakultas Hukum Universitas Lampung.

Jimly Asshiddiqie. 1998. "UUD 1945: Konstitusi Negara Kesejahteraan dan Realitas Masa Depan", Pidato Pengukuhan Jabatan Guru Besar Tetap Madya, Tanggal 13 Juni. Jakarta: FHUI. 


\section{BIODATA PENULIS}

Nama $\quad$ : Dr. Deasy Soeikromo, S.H., M.H

Pekerjaan $\quad$ : Dosen Fakultas Hukum Universitas Sam Ratulangi Manado

Jabatan : Lektor Kepala

Nomor HP ～： 081340584698

E-mail $\quad$ : soeikromod@yahoo.co.id

Alamat Kantor : J1. Kampus Unsrat Kleak Bahu, Manado, Sulawesi Utara95115 